\title{
The Place of Emanuel Swedenborg in the Spiritual Saga of Scandinavia
}

\section{Introduction}

Between 1749 and 1771 the Swede Emanuel Swedenborg (1688-1772) wrote and published eighteen religious works in Latin that he claimed were the foundation of a new Christian religion. He wrote that he had been called by God to unlock the spiritual secrets of the Bible through the doctrine of correspondences; to reveal the nature of the spiritual world based on experience in that realm; and to explain the keys to living a heavenly life. Stating in his last work, True Christianity (paragraph no. 779) ${ }^{1}$ that he was called only to write and publish, Swedenborg never attempted to found a church. Swedenborg published his books in Amsterdam and London, and if his 1758 print runs of 1,000 for five different works are typical, he had thousands of books available to distribute throughout Europe and he did so. However, the number of books in Scandinavia at the time of his death was probably fairly small.

In 1772 there were less than a dozen readers in all of Europe, and only a small handful in Scandinavia. While awareness, education, and access are necessary prerequisites to the possibility of responding to these works, interest is essential. From the beginning, and over the years since their publication, individuals motivated to explore them seem to fall into the following categories: religious virtuosi/seekers; philosophers; occultists; artists, poets, and, writers. Without question, a particular individual may be motivated by more than one of these categories-August Strindberg (1849-1912) provides an excellent example of a person with multiple levels of motivation stimulating his encounter with Swedenborg.

1 References to material in Swedenborg's work are always given by citing paragraph numbers. 
Despite the obstacles mentioned above, Swedenborg's works have been and continue to be read and responded to in Scandinavia. However, the motivation for the response has varied; and the distribution has been uneven. Not surprisingly, the strongest and most sustained response has occurred in Sweden, Swedenborg's homeland. Denmark, where Swedenborg frequently visited during his lifetime, witnessed an early stirring of interest among a few of his acquaintances, but nothing developed. In the nineteenth century he was sporadically noticed, and eventually a small circle of readers emerged that has continued into the twenty-first century. In Finland there was a flurry of interest among the Swedish-speaking Nordenskjöld family soon after Swedenborg's death. Their involvement played a significant role in the early history of Swedenborgianism in Sweden, France, and England; and while some family members were still connected with Swedenborgianism at the beginning of the twentieth century, they no longer resided in Finland. There was no discernable response in Norway until the middle of the nineteenth century when members of the Boyesen family discovered the teachings of Swedenborg. One member of the family chose to raise his family based on them, and another member became the first Swedenborgian minister in Denmark. There appears to have been little, if any direct intellectual interest in his works in Norway until fairly recently. Today there is a small circle of readers in Oslo.

Those who have responded to Swedenborg in Scandinavia fit all the categories of motivation as outlined above. Their stories will not be discovered, however, until a comprehensive examination of Swedenborg's place in Scandinavia is written. This article is only an initial attempt to fill that need.

The focus of this article so inspired me that I actually wrote a small monograph that would be impossible to present. I explored issues in Swedenborg scholarship, in general and with reference to Scandinavia; reviewed Swedenborg's relationship to both esotericism and Lutheranism, and then examined the history of the reception of Swedenborg in the four nations of Scandinavia. In this article I will make a few remarks about issues on scholarship, and then turn my attention to three men with three different relationships to Swedenborg's religious writings, they are Edvard Munch (1863-1944), Søren Kierkegaard (1813-55), and August Strindberg (1850-1912). I will then make an assessment of Swedenborg's contribution to Scandinavia. 


\section{Issues in Swedenborg Scholarship and Scandinavia's Spiritual Saga: Some Problematics}

Over a decade ago, I wrote an article entitled 'Swedenborg's Place in Modern Western Esotericism', published in Faivre's and Hanegraaff's Western Esotericism and the Science of Religion. While my 1998 article does not suggest that he was a central figure in European Illuminism, it does demonstrate that he was far from marginal.

Since that article was published, I have explored Swedenborg's relationship to both European and American writers and artists and have found that he was a significant influence on many individuals who made ground-breaking contributions to modern Western culture, some of whom had esoteric interests. For example: the English artist, William Blake (1757-1827), the French novelist Henri Balzac (1799-1850), the American writer Edgar Allan Poe (1809-49), the American poet Walt Whitman (1819-92), the French poet Charles Baudelaire (1821-67), The Russian novelist Fyodor Dostoevsky (1821-81), the American landscape painter George Inness (1825-94), the French painter Paul Gauguin (1848-1903), and the Argentinean writer Jorge Luis Borges (1899-1986).

Edgar Allan Poe is a particularly interesting case in point, because his work had broad influence on Scandinavian writers and artists toward the end of the nineteenth century. I explored Poe's connection to Swedenborg in an article titled, 'Light and Dark in the Art of Edgar A. Poe' (Williams-Hogan 2004).

Poe, who reviewed books for a literary magazine seems to have read Swedenborg's Heaven and Hell in its second American edition published in 1837. Not only does he mention Swedenborg's Heaven and Hell in his popular short story 'The Fall of the House of Usher' published in 1839, but a passage from that work (paragraph no. 528) appears to be source of the story itself. The paragraph is a discussion about people who renounce the world and live for the spirit alone, much like Roderick Usher. The number not only expounds on the theme of 'The Fall of the House of Usher', the word picture it employs appears to be the source of the imagery used by Poe to describe the house itself. The number concludes:

...This is because living an inner life and not an outer life at the same time is like living in a house that has no foundation, that gradually either settles or develops gaping cracks or totters until it collapses (Swedenborg 2002: paragraph no. 528). 
The picture described in Heaven and Hell foreshadows Poe's own words depicting the house and its ultimate collapse at the end of the tale and strongly suggests that it was Poe's inspiration.

There are several implications of this case: first, knowledge of Swedenborg's oeuvre matters. However, since Swedenborg's perspective is not part of the 'taken for granted' intellectual heritage of Western scholars; even in the area of religion, his contribution to a specific writer, philosopher, or artist can go unnoticed, particularly if the person does not personally mention Swedenborg.

There are several reasons why a person, whose work may be of interest to a researcher, may not have mentioned his or her interest in Swedenborg: one important one would be the long reach of Kant's critique of Swedenborg in Dreams of a Spirit Seer (1766), with its implication of Swedenborg's fantasy or madness. Another reason, quite simply could be church censorship. Surely these issues weighed on creative individuals who had read Swedenborg in the late eighteenth century and long into the nineteenth, and perhaps they weighed even more so, in Scandinavia, where the traditional aspect of social structure lingered longer, and where the Lutheran Church maintained a tight grip on society. In Scandinavia politics may also have played a role.

If they read Swedenborg in Latin, the question is merely what books or portion of works did they read. If they read him in translation, the question becomes: translated by whom and when?

\section{Swedenborg's Influence on Scandinavian Art and Letters}

In order to explore Swedenborg's influence on Scandinavian art and letters, his relationship to three men will be reviewed: the Norwegian, Edvard Munch, the Dane, Søren Kierkegaard, and the Swede, August Strindberg.

Munch provides an opportunity to examine Swedenborg's influence second hand, so to speak. As I write, there is no known evidence that Munch knew of, read about, or actually read Swedenborg. That being said, it is my contention that he could have been influenced by Swedenborg, nonetheless. Investigating this possibility provides an opportunity to examine the avenues of Swedenborg's secondary influence through literature that help to create in the 1890s a period of 'spiritual breakthrough', according to the Danish poet and playwright, Helge Rhode in a 1913 lecture (Anderson 1973: 12). What Rhode said was that the underlying motivation of the art and literature of that period was 'a 
craving for a new law of life or in any case for a new illumination of life' (Anderson 1973: 12).

\section{Munch with Swedenborg in the Background}

Danish author Johannes Jörgensen's 1916 Autobiography sets the stage for a discussion of Swedenborg's place in Scandinavian art and letters toward the end of the nineteenth century. On the one hand, Swedenborg's contribution to the conversation was clearly taken-for-granted; on the other, it was masked through second hand presentations of his thought in the works of the many authors and artists who also served as wellsprings for the creative vision that emerged at the century's end.

It is possible to see Swedenborg as a taken-for-granted figure in the following two quotes of Jörgensen, in discussing his friend Mogens Ballin:

It was into the Paris of Symbolism that he fell in 1891 when only twenty years old. With all the enthusiasm of his youth and the ardour of his race he joined himself to the newest of the new; he was one of the happiest among the happy, cosmopolitan and youthful crowd of the Boulevard Saint Michel and the Closerie des Lilas. But he did not confine himself to drawing and painting; he also read and thought. Sâr Péladan made an impression on him; he read Swedenborg. . . (Jörgensen 1928: 166.)

The three artists, then, Ballin, Verkade and Sérusier, spent a summer together in Brittany. First at Pont-Aven, then at Huelgoat, finally in Pouldre. In the autumn of 1891 Ballin returned to Copenhagen. I saw him at the studio of his friend, Clément, one day in the following February-very talkative, his fingers yellow from cigarette making, expounding Symbolism, Rosicrucianism and the doctrines of Swedenborg. . . (Jörgensen 1928: 167.)

Swedenborg's enormous contribution to Symbolism will be discussed shortly; but first, again drawing on Jörgensen's Autobiography, let me list some of the authors he read, who can be shown to have been influenced by Swedenborg: Goethe and Poe are the very first to be mentioned, then follows Wilde, Dostoevsky, Strindberg, Madame de Staël, Coleridge, George Sand, Balzac, Baudelaire, Madame Blavatsky, and Browning. ${ }^{2}$ 
These authors all focused on something higher than nature, and something more interior. As Jörgensen himself said, 'But, as everywhere else, the exoteric doctrine differed from the esoteric; the kernel was one thing, the shell another' (Jörgensen 1928: 83).

In reading both Poe and Dostoevsky, Swedenborg is also being read, not directly, but indirectly. What they seem to highlight, according to Anderson is 'the realness of the "unreal"', the irrational element, and an awareness of 'all the hidden currents in the spirit of man' (Anderson 1973: 6). In 1889 the poet and Symbolist, Charles Morice, compared Victor Hugo and Poe. He wrote that while Hugo saw the grotesque and the horrible from the outside, Poe saw it within the soul, the heart, the mind of a person: 'it is to our souls, and not our eyes, that he appeals' (Anderson 1973: 7).

According to Anderson, Jörgensen saw Poe as 'the proto-Symbolist of modern times' (Anderson 1973: 36). In Poe's visions he found all the elements of Symbolism: 'the inward search for perfect harmony, the essential unity of a world only apparently chaotic, and the theatricality of the artist's powers of mind in giving expression to these mysteries' (Anderson 1973: 36). The world after all mirrors the will. This view echoes Swedenborg, who wrote in the very first line of Divine Love and Wisdom, 'that love is the life of every human being'.

According to Czeslaw Milosz, Dostoevsky also was familiar with Swedenborg. He owned Heaven and Hell and two other works closely associated with him (Milosz 1975). ${ }^{3}$ Milosz finds Swedenborgian elements in Crime and Punishment, The Idiot, and The Possessed. His influence on The Dream of a Queer Fellow is also quite clear. In Crime and Punishment he points to several doctrines of Swedenborg's that Dostoevsky employed, such as the doctrine of correspondences, and the concept of the Grand Man. He, like Poe, was fascinated with Swedenborg's idea that a human being, by virtue of his mind, lives in the spiritual world. This endows human actions and human events with extraordinary meaning. A person may choose to live connected to heaven, or to hell. Heaven or hell is constructed from the states of human beings who live there.

The three books are all in Russian. The other two are: A. N. Aksokov, The Gospel According to John with an Exposition and a Discussion of their Spiritual Meaning According to the Teaching on Correspondences (Leipzig, 1864); A. N. Aksokov, The Rationalism of Swedenborg: A Critical Analysis of His Teaching on the Holy Writ (Leipzig, 1870). 
The projected images derive from their states of mind. Heaven and hell does not so much depict sociological structures, as it depicts or projects psychological states. Swedenborg in his religious works was one of the first authors to portray human inwardness. Poe, as well as Dostoevsky draws on this new reality.

Poe and Dostoevsky share with their readers the inner realities of dark, troubled, and troubling people. It is almost as if they have descended into hell to find them, but into a very special hell, unlike the fires of Dante's Inferno, they present the reader a series of private hells, individual, and personal dark places where the terror is internal and self-generated-they, in effect, painted portraits of the inhabitants of Swedenborg's hell.

In any case, both these men spoke with authority to the Symbolist painter Edvard Munch. In fact, 'it is reported that he once declared that Poe and Dostoevsky had made "the greatest" impact on his life' (Anderson 1973: 43). I recently read in a review of a new biography of Munch by Sue Prideaux (Yale, 2006) that Munch's father read Poe and Dostoevsky aloud to his young children. If that is the case, these works made early and deep impression on him (Bering 2006). Prideaux also cites Dostoevsky's influence on Munch: 'Just as Leonardo da Vinci studied human anatomy and dissected corpses, so I was trying to dissect souls. No one in art has penetrated as far as Dostoevsky into the mystical realms of the soul, toward the metaphysical, the subconscious, viewing the external reality of the world as merely a sign, a symbol of the spiritual and the metaphysical' (Bering 2006).

Munch as a young man in Christiania formulated an artistic manifesto, in which he wrote:

We want more than a mere photograph of nature. We do not want to paint pretty pictures to be hung on drawing room walls. We want to create, or at least lay the foundations of an art that give something to humanity. An art that arrests and engages. An art created of one's innermost heart. (Eggum 2007.)

And in an often cited note from his diary, he wrote: 'We should no longer paint interiors, with people reading and women knitting, they should be people who live, breathe, feel, suffer and love' (Eggum 2007). While he wanted his art to be personal, it was not for the sake of expressing mere subjectivity that he created, rather as Eggum writes, 'he aimed to establish universal values through individual ones by crystallizing images of man's deepest emotions—of love, death and anxiety, images 
that retained primitive qualities evidently forgotten by the bourgeois civilization of his time' (Eggum 2007).

In the 1880s Munch travelled to Paris and became immersed in the Symbolists' milieu. While there were many streams that fed into the Symbolist aesthetic in France, Filiz Eda Burhan in her 1979 dissertation investigating the formation of that aesthetic suggests that psychology and the occult sciences were particularly important. Her dissertation demonstrates that Swedenborg provided the Symbolists with psychological and occult insights. He supplied them with both a vision and a methodology. He was appropriated directly by Baudelaire, Aurier, Sérusier, and Gauguin, and indirectly through the works of Balzac and Poe.

Baudelaire's influence on the Symbolist movement is well known. Burhan's work documents that Balzac had a seminal influence on the movement that rivalled Baudelaire's. The Symbolist era witnessed a revival of occultism and a revival of interest in the Balzac oeuvre, particularly the trilogy, Le Livre mystique, that includes Louis Lambert, La Recherche de l'absolu, and Seraphita. According to Burhan, 'the series of articles entitled "Balzac Forever", which appeared in the Symbolist journal, $\mathrm{La}$ Cravache, was almost exclusively composed of excerpts from Balzac's mystic novels. ..' (Burhan 1979: 33). There was also an article entitled 'Balzac Occultiste', in an issue of La Plume dedicated to esotericism; and the critic, Charles Morice, urged Symbolist readers to use Louis Lambert and Seraphita as spiritual guides (Burhan 1979: 34). And the Symbolist Paul Sérusier 'encouraged his Nabi friends Jan Verkade and Mögens Ballin to read these novels as part of their "spiritual education"' (Burhan 1979: 34). Sérusier took his own lesson to heart, because 'he claimed that he read one page of Louis Lambert every day before he began to paint' (Burhan 1979: 142).

The trilogy is Balzac's version of the Divine Comedy, with Seraphita revealing the highest ideal. In Seraphita, Balzac pays direct homage to Swedenborg. In the novel Balzac relates many of the details of Swedenborg's life, his clairvoyant experiences, and his religious doctrines, mixed with his (Balzac's) own ideas of reincarnation. This book, as Burhan has documented, is a potent visionary script for esoteric practitioners, including writers and artists.

Albert Aurier was another Symbolist who took this vision to heart. In his article 'Le Symbolism en Peinture-Paul Gauguin' he denounces Impressionism, and "claimed that the "true and absolute artist" was the one who could join Swedenborg in the glorious cry, "This same night the eyes of my internal man became open: they permitted me to see into 
the heavens, into the world of ideas, and into hell"' (Burhan 1979: 128). ${ }^{4}$ Aurier believed that this shift in perception from the corporeal eye to the soul led to a higher form of cognition. This superior cognition is the foundation for understanding correspondences (Burhan 1979: 129).

Burhan states the significance of this for the Symbolist Movement:

Aurier's double reference to Swedenborg, in an article which was designed as a Symbolist manifesto, not only demonstrates that mystical theory had indeed been a contributing factor in the formation of the Symbolist aesthetic stance, but it also indicates the precise nature of its contribution. For the quotation of these two statements by Swedenborg allowed Aurier to define perception as a spiritual, subjective vision which revealed the world to be a system of symbolic representations, a definition which was, of course, the axis of the entire Symbolist aesthetic (Burhan 1979: 129).

The Symbolists used Swedenborg not only to redefine the location of true perception, but they also drew inspiration from him concerning the occult power of clairvoyance. The ideal Symbolist artist was a 'sublime voyeur' (Burhan 1979: 131). Gauguin took delight in quoting Swedenborg (perhaps incorrectly) that artists are 'the favorites of God' (Burhan 1979: 131). Gauguin expanded on this idea in the Cahier pour Aline and his review of the artist Armand Séguin. To make his point, he quotes the Swedish visionary: 'There is in the firmament a book in which the eternal law of harmony and beauty is written', and Gauguin believed that Swedenborg claimed that only artists have the ability to decipher the meaning of the divine book. Gauguin's interpretation of Swedenborg gave him faith that artists can both read and write (through their own creations) this divine script (Cheetham 1987: 17). In addition, in his text, on several occasions he exclaims: 'Et Swedenborg était un savant' (Cheetham 1987: 17)!

Swedenborg, via Balzac's Seraphita and Louis Lambert, also influenced the Symbolist's sense of colour and proportion. As Burhan writes:

Much can be said about Honoré de Balzac's Seraphita, a novel which the artists and critics of the Symbolist Movement both knew and

4 Swedenborg did not use the phrase the world of ideas, but rather the world of spirits. 
loved. Liberally laced with citations from Swedenborg, Seraphita presented all the essential features of the theory of correspondences which later appeared as the basic element of the Symbolists aesthetic program. (Burhan 1979: 140.)

In the book's last reference to correspondences, they could discover the intimate relationship between music and colours. In other parts of the text that referred to Swedenborg, they could also discover the underlying principles of straight and curved lines, noting that horizontal lines measure what is inert, and vertical lines what is living. They understood that the 'real' quality of these lines is not found in nature, but through one's spirit (Burhan 1979: 141).

It is hoped that this discussion has demonstrated the importance of Swedenborg to avant-garde artists and intellectuals throughout the nineteenth century. He was, so to speak, a 'cutting edge' to their cutting edge. He was sometimes read in abridged formats, and even as in Balzac's Seraphita, in an abridged abridgement. He was sometimes, but not often, read in the original, and even then it could be in translations that had questionable fidelity to the original. He was however, an ongoing continual part of the conversation whether through Poe, and Dostoevsky, the Symbolists or even others that have been mentioned but not discussed in this article. In these circles he was not generally read as a theologian, although his authority was used to give an imprimatur to the concept of 'artist as revelator and priest'.

With regard to Edvard Munch in particular, what do we know? First, although there are no references to Swedenborg in his written corpus or library, it is import to point out that Munch led the unsettled life of a wanderer until he settled in Ekely in 1916. Thus, the library he owned at his death is not necessary representative of his life-long reading. ${ }^{5}$ And while Swedenborg is not mentioned in his diary; his name did not find itself in Kierkegaard's either and yet, he both owned and marked copies of Swedenborg's religious works. Second, we do know that he read authors such as Poe and Dostoevsky, whose visions drew heavily of Swedenborg's insights concerning the inner reality of the 'darkness and light' found in human nature. Third, he considered himself a Symbolist and a northern representative of that school. He painted to express the library in Oslo. 
universal human in what he saw was the 'Frieze of Life', that also intimately reflected his own inner emotional life. He wrote:

In reality, my art is a confession made of my own free will, an attempt to clarify my own notion of Life ... at bottom it is a kind of egoism, but I shall not give up hope that with its assistance I shall be able to help others achieve their own clarity (Bischoff 2000: 42).

He also said, in a statement reminiscent of Gauguin that:

I painted the lines and colors that affected my inner eye. I painted from memory without adding anything, without the details that I no longer saw in front of me. This is the reason for the simplicity of the painting, their obvious emptiness. I painted the impressions of my childhood, the dull colors of a forgotten day (Bischoff 2000: inside front cover).

His work also illustrates the Symbolist understanding of the inner meaning of the horizontal and vertical lines, particularly in his last painting, By the Window, done in 1940. In Bischoff's discussion of this painting he writes:

In this last painting, the polarity of Life and Death has produced a work of striking power. The strong red of the face and background, with the weighty blue-green of his clothing, establishes a solid zone of Life which is emphatically counterpointed with the realm of Death visible outside the window, where ice and snow hold Nature tight in a frozen grip. The vertical structure of the picture reminds us of the contrast between standing and lying. Life represents a temporary victory over the force of gravity and over matter: we stand, upright, but one day we must lie down, to die. Life is an image of victory. And this late painting reconciles Life and Death, the vertical and the horizontal, movement and stasis. (Bischoff 2000: 93.)

In this painting we see the Symbolist use of colour as well as structure. It is interesting to note that red corresponds to love, and white to truth in Swedenborg's teaching on correspondences. The red band of colour, the colour of life/love claims only a quarter of the canvas, and almost appears to be retreating, shrinking in the face of death and winter. But Munch's face is defiantly still red, filled with life/love. 
Like no other, he painted the 'modern life of the soul'. Insofar as the life of the soul in modern times depicts the inner nature of both heaven and hell, we can see Munch providing the visual images of Swedenborg's own work Heaven and Hell. Swedenborg wrote a visual description of our inner human life made 'real' in the afterlife. Munch knew that world intimately, not necessary from reading Swedenborg, but from experience. We cannot photograph our inner life, but it can be described and painted. As Munch said: 'The camera cannot compete with the painter as long as it cannot be used in Heaven or Hell' (Bischoff 2000: 85).

As Bischoff writes, 'Heaven and Hell were all too familiar to Munch. His whole life long he was forever journeying from one to the other. The details of Munch's landscapes. . .were never merely naturalistic reproduction. They were also symbols expressing a personal language of the soul.' (Bischoff 2000: 85.)

It is clear that Swedenborg and Munch shared a perception concerning the nature of Heaven and Hell, and they both sought to confront their audience with its wonderful and fearful, self-made reality. Was Munch knowingly influenced by the visions of the Swedish mystic and his fellow 'seer'? The man who said he was enabled to see into heaven and hell, 'in hopes of shedding light where there is ignorance, and of dispelling scepticism' (Swedenborg 2002: paragraph no. 1). Perhaps not, but the weight of evidence suggests otherwise.

\section{Kierkegaard with Swedenborg in the Middle Ground}

In shifting from exploring the possibility of a connection between Swedenborg and Munch, to some actual, although, as yet, not clearly defined relationship between Swedenborg and Søren Kierkegaard; it is clear that the methodological problems are quite different. Knowing that Kierkegaard owned and read Swedenborg, is interesting and even exciting, but it is only a tenuous beginning to the much more important question of 'So what?' What does knowing about this connection mean, and what, if any, importance does it play in understanding Kierkegaard's philosophy and his stance toward Christianity?

While these are important questions, and I will certainly address them, I will also say that, at this moment, I am really only setting up the problem, putting it into the public academic domain, so to speak; and I must leave it to others, and perhaps my own future research for more definitive assessment. This qualification is necessary because there are 
still many unknowns with regard to the material I will report on and analyze; and of course, there is the obvious problem that I am not a Kierkegaard scholar. While initially there are some advantages, to coming at Kierkegaard as an 'outsider' and a Swedenborg scholar at that; however, in the long run, my lack of intimate knowledge of his oeuvre and the scholarship surrounding it may hamper my ability to 'see' clearly what this material represents or means.

\section{Kierkegaard's Encounter with Swedenborg's Religious Writings}

Given that necessary background, it is now useful to turn to what I have in hand with regard to Swedenborg and Kierkegaard.

I have 46 pages photocopied from the works of Swedenborg listed in the Acktionsprotokol over Søren Kierkegaards Bogsamling (Rohde 1967). Swedenborg's works are listed as 810-11, and 812-13 on page 35 of the original protocol. They are in the Hovedsamling.

They are listed as follows:

810-11 Swedenborg, Emanuel, Opuscula. 4to. London 1758 \& 63. [ : De Coelo et ejus Mirabilibus, et De Inferno. Londini 1758. - Doctrina Novæ Hierosolymæ de Domino. Amstelodami 1763.] 4-2-8 Lynge til kgs. Bibl. [Nu: KB. F\& F 1961, p. 109 sp. I. Samt. Kartonnage.] (Rohde 1967: 56.)

812-13 Swedenborg, E., die ganze Theologie der Neuen Kirche, aus dem Lat. 2 Bände. Basel 1795. 1-3-0 kgs. Bibliotehek. [NuL KB. F \& F 1961, p. 109 sp. I. Købt hos Schublthe 10.2.1843, F \& F 1961, p. 124. Samt. halvbd.; N. C. Møller? F \& F 1961, p. 114.] (Rohde 1967: 56-7.)

The marked pages are all from Swedenborg's first editions. ${ }^{6}$ However, the titles in the catalogue do not do full justice to the works marked by Kierkegaard. The Doctrine of the Lord, also contained the Doctrine of the Sacred Scriptures, the Doctrine of Life, and the Doctrine of Faith. These are all short works by Swedenborg. The marked pages come from the Doctrine of the Lord (7 pages, and 5 numbers), the Doctrine of the Sacred Scriptures (17 pages and 25 numbers), and the Doctrine of Life (1 page and

6 Verified by Jonathan S. Rose, PhD, July 18, 2007, Neo-Latin scholar and translator of Swedenborg's theological works. 
4 numbers). There were no marked pages from the Doctrine of Faith. In addition, there were no marked pages from Heaven and Hell, but there were a considerable number of pages taken from Swedenborg's 1763 Divine Love and Wisdom (15 pages, and 30 numbers); and a few were taken from its companion work Divine Providence (6 pages and between 7-11 numbers). ${ }^{7}$ Neither Divine Love and Wisdom nor Divine Providence are listed in the Auction Protocol, however, they must be the Opuscula listed with a 1763 date.

The Auction Protocol does not list the date that Kierkegaard acquired the Latin editions, but it does list the fact that he bought the two-volume German Overview of the Theology of the New Church on February 10, 1843 , ten days before he published Either/Or, which is dated February 20, 1843.

Since I have not had access to the German Overview, and do not know what it contains or, if it, too, was marked, at this time, I cannot comment on whether or not it had any impact on Either/Or. However, what I can do is: first, to list the works of Kierkegaard in which I have found similarities to ideas he marked in the Latin editions of Swedenborg; second, to give a brief overview of those ideas; and third, to look briefly at those works of Kierkegaard and make a few comparisons. And, then finally come back to the question of 'So what?'

In order to make this effort manageable, I am drawing the list from the book The Essential Kierkegaard, edited by Howard and Edna Hong (2000). From that work, the list includes:

Either/Or dated 1843

Four Upbuilding Discourses dated 1844

Concluding Unscientific Postscript dated 1846

Upbuilding Discourses in Various Spirits dated 1847

Works of Love dated 1847

The Difference Between a Genius and an Apostle dated 1849

For Self-Examination dated 1851

Judge for Yourself! For Self-Examination Recommended to the Present Age

Second Series dated 1851-2. 
In 1763 Swedenborg published the four doctrinal works owned by Kierkegaard. They provide a good brief overview of the essential doctrines for the New Jerusalem - the holy city mentioned in the book of Revelation. These texts present teachings concerning the nature of God, the role of sacred scripture, the fact that life in the New Jerusalem requires living according to the Ten Commandments, and the nature of faith and its role in life.

The Doctrine of the Lord is 64 pages long and contains 65 numbers. Kierkegaard only marked 8 per cent of the passages in this work.

The Doctrine of Sacred Scripture is 54 pages long and contains 90 numbers. He marked 28 per cent of the passages in this work.

The Doctrine of Life is 36 pages long and contains 113 numbers. Kierkegaard marked 4 per cent of the passages in this work.

Divine Love and Wisdom is 151 pages long and contains 432 numbers. Kierkegaard marked more numbers in Divine Love and Wisdom than any other book of Swedenborg's that he owned, and yet they represent only 7 per cent of the whole work.

Divine Providence is 214 pages long and contains 340 numbers. The numbers that he marked represent only 3 per cent or the entire work.

\section{Some Key Teachings of Swedenborg Marked in Works Kierkegaard Owned}

The essential idea of the Doctrine of the Lord is that 'God is one in person and in essence, and this God is the Lord'. Kierkegaard marked the phrase, and 'this God is the Lord' (paragraph no. 65). Swedenborg also demonstrates in this work that Jehovah and Jesus Christ are one; and that they became fully one through the Passion of the Cross, which was the last temptation of Christ. It was the means whereby his divine self was united with his human self. The Lord's divine nature is called the Father, and his human nature is called the Son. Redemption and Salvation are attributes proper to his human.

Swedenborg in his work on Sacred Scripture calls the Sacred or Holy Scripture the Word of God. He always refers to the Bible as the Lord's Word or simply the Word. In the first number that Kierkegaard marked, Swedenborg states that there is holiness in every sentence of the Word, and that it is through the Word that a person is conjoined to heaven. The Word, he writes, opens heaven for those who read it from the Lord and not from what is their own. The Word contains an internal or spiritual sense. It contains this sense like the body contains the soul. Just as the 
soul gives life to the body, so the spiritual sense gives life to the letter, but is not in the letter, or the literal sense.

Kierkegaard also marked passages in the Sacred Scripture in which Swedenborg explained the darkness that had enveloped the Christian world, because so many had fallen into the love of dominion and consequently had confirmed themselves in falsities; as well as those who had separated faith and charity, and who worshipped God in three persons-causing heavenly truths to be hidden from them (paragraph no. 24).

A summary of what Kierkegaard found of interest in the Doctrine of Life is the fact that belief in the Lord cannot be just an acknowledgment that he exists, but must be demonstrated by acting according to his words; faith does not exist with the evil, even if they suppose themselves to have it; spiritual faith exists with those who do not commit sins, because they do things that are good; and they do what is good not from themselves but from the Lord.

What Kierkegaard seems to find interesting in Divine Love and Wisdom is that, according to Swedenborg, there is no continuum between the natural physical world and the spiritual world. Thus, when we die we leave the world of nature completely behind. 'It is a case of before and after, with no communication except by correspondence' (paragraph no. 90). Spiritual warmth and life derive their essence from a sun that is nothing but love, while physical warmth and light contain no life whatsoever. It is love that generates warmth and wisdom that generates light. It is clear that love and wisdom are spiritual qualities; it can be demonstrated that spiritual life is distinct from natural physical light, because, it is possible to have discernment which is a form of seeing, even in the dark. The light of discernment comes from a different source (paragraphs no. 90-9).

Kierkegaard noted in Divine Love and Wisdom that Swedenborg mentioned that there are three degrees of the mind that are opened in sequence. Swedenborg states that while people are aware of the horizontal level and the gradations it contains, they are nonetheless not aware of the vertical level-that is the distinct difference between ends, causes, and effects.

Searching for causes on the horizontal level can lead to errors and distortions of the truth. Genuine understanding requires knowledge of both the vertical and horizontal levels. Swedenborg states that this is why he devoted a whole section of his book to explaining the differences between (what he calls) discrete and continuous degrees. He also stated that his purpose in the work Divine Love and Wisdom was to 
uncover causes and to see effects on that basis. In doing so he hoped to dispel the darkness that envelops people in the church concerning God, the Lord, and other divine matters that are referred to as 'spiritual' (paragraphs no. 187-8).

In Divine Love and Wisdom Swedenborg posits three levels which follow one from another in sequence like a purpose, a means, and a result. However, knowing these things without applying them to actual events is only abstract knowledge. And he continues, 'Thinking only about abstractions is like something ethereal that dissipates; but if these abstract principles are applied to things of an earthly nature, then they are like something we see with our own eyes on earth, and they stay in our memory' (paragraph no. 189).

Swedenborg developed this ideal in Divine Love and Wisdom further and states that 'these three vertical levels exist in each of us from birth and can be opened in sequence. As they are opened, we are in the Lord and the Lord is in us.' (Paragraph no. 236.) Swedenborg calls these three levels earthly, spiritual, and heavenly. The earthly level opens gradually and takes us to the summit of intelligence called rationality. Rationality by itself, however, cannot open the next level, which is called spiritual. This can only be opened by a love of being useful, which is a spiritual love, a love of the neighbour. The heavenly level is opened by a heavenly love of being useful, which is love of the Lord. Loving the Lord is applying the teaching of the Word to our lives. The three levels are opened by three different loves-love of learning, love of the neighbour, and love of the Lord (paragraph no. 237).

Kierkegaard's interest in Divine Providence centres on how human beings are united with the Lord. He highlights several numbers that focus on the role of freedom and rationality in the process of human reformation and regeneration. Recognizing that all good and truth comes from the Lord makes reformation and regeneration possible. Swedenborg relates that the following is a truth that is widely accepted: people who teach the truth and live well are saved, but those who teach truth and do not live well (do evil) are not (paragraph no. 91:3).

\section{Similarities between the Thought of Swedenborg and Kierkegaard}

The first similarity between Swedenborg and Kierkegaard occurs in Either/Or: the text in which Kierkegaard introduces the dialectical progression of existential stages. In Either/Or he introduces the first two stages: the aesthetic, and the ethical; in later works he articulates the re- 
ligious (Stanford 2006). This first stage is characterized by immersion in sensual experience, preference for the possible over the actual, egotism, fragmentation of experience, nihilism, and ennui. The second stage is characterized not so much by choice as by choosing. 'On the whole, to choose is an intrinsic and stringent term for the ethical. Wherever in the stricter sense there is a question of an Either/Or, one can always be sure that the ethical has something to do with it. The only absolute Either/Or is the choice between good and evil, but this is also absolutely ethical.' (Hong \& Hong 2000: 73.)

Kierkegaard continues:

But what is it that I choose-is it this or that? No, for I choose absolutely, and I choose absolutely by not having to choose this or that ... and what is the absolute? It is myself in my eternal validity. . . But what is this self of mine? If I were to speak of a first moment, a first expression of it, then my answer is this: it is the most abstract of all, and yet in itself it is also the most concrete of all-it is freedom. (Hong \& Hong 2000: 79-80.)

Kierkegaard explores the religious stage in his Four Upbuilding Discourses, written in 1844. In this essay he states: 'To Need God is a Human Being's Highest Perfection' (Hong \& Hong 2000: 87). He writes 'that it is the saddest thing of all if a human being goes through life without discovering that he needs God' (Hong \& Hong 2000: 87). The human being needs God, because the higher he strives the more he comes to know that in himself, 'he is capable of nothing, nothing at all' (Hong \& Hong 2000: 87). But Kierkegaard assures his reader that 'God in heaven is capable of all things' (Hong \& Hong 2000: 87).

Kierkegaard asserts that there is a correspondence between God and man. Thus, the question is, whether or not an individual is happy about this good fortune of correspondence, or whether the individual might prefer not to correspond to God, to prefer the be capable of something himself and thus to not correspond to God completely (Hong \& Hong 2000: 88). It is only through accepting the view that God is man's highest perfection, that man can begin to view himself, and it is through this view that man learns to know himself. And for the person who does not know himself, his life is, in the deeper sense, indeed a delusion (Hong \& Hong 2000: 88).

Needing God allows an individual to know his deeper self, and through his deeper self then he can explore his first self. His deeper self can have the first self view the world in such a way that it no longer 
appears attractive to the first self. This process continues to the point that an individual also learns to question the source of 'wisdom' of his deeper self. Again conflict arises in Kierkegaard's understanding of the struggle, and again a person learns 'that he himself is capable of nothing at all' (Hong \& Hong 2000: 91). This is the point of self-knowledge.

In his essay For Self-Examination written in 1851, Kierkegaard discusses what Christianity requires of an individual, and how the individual can fulfil these requirements. He writes:

Christianity's requirement is this: your life should express works as strenuously as possible; then one thing more is required-that you humble yourself and confess: But my being saved is nevertheless grace (Hong \& Hong 2000: 396).

In what follows in this essay Kierkegaard discusses the history of Christianity, and the important fact that the concern of meritoriousness ultimately led to the abandonment of works. While Luther wanted works to be a witness for the truth, Kierkegaard writes: that 'the secular mentality, which understood Luther perfectly, took meritoriousness away altogether-including the works' (Hong \& Hong 2000: 396).

But says Kierkegaard, James says that we must not only be hearers of the Word, but doers of it. However, in order to be a doer of the Word, one must hear or read it. This leads Kierkegaard to ask a question and then provide two assertions as answers. The Question is:

What is required in Order to Look at Oneself with True Blessing in the Mirror of the Word (Hong \& Hong 2000: 396)?

The first requirement is that you must not look at the mirror, observe the mirror, but must see yourself in the mirror (Hong \& Hong 2000: 396).

God's Word is the mirror (Hong \& Hong 2000: 397).

The second requirement is that in order to see yourself in the mirror when you read God's Word you must (so that you actually do come to see yourself in the mirror) remember to say to yourself incessantly: It is I to whom it is speaking; it is I about whom it is speaking (Hong \& Hong 2000: 398-9). 
Kierkegaard ends this essay stating that what is required is that each human being ought 'to understand what a blessing it is to him that you take the power and give life' (Hong \& Hong 2000: 403)!

\section{Analysis of the Similarities}

Kierkegaard and Swedenborg had similar views of human development. They both discuss three levels: for Swedenborg it is the earthlyminded; the spiritual-minded, and the heavenly-minded, and for Kierkegaard, it is the aesthetic, the ethical, and the religious. The characteristics of the three levels are also remarkably similar: sensuousness defines the first level, ethics, or sociability / neighbourliness defines the second level, and love of God defines the highest level. To love God for both men is to hear his Word, abide by it, and to do it! Both focus on the need for works, and the fact of grace. Both men use the term the Word of God, or the Word of the Lord, and do not use the more common term, the Bible. Swedenborg speaks of God as One, and discusses the Lord's oneness at some length. Kierkegaard explicitly focuses on one God, by continually saying God and, in the passages that I have examined he never refers to the Trinity. One God makes demands in the Word, not three, and 'the God in heaven is capable of all things' (Hong \& Hong 2000: 87). Kierkegaard even has a critique of Lutheranism that is similar to Swedenborg's.

This brief review is focused on the similarities not on the differences, of which I am sure there are many. The point is, that there are sufficient similarities to suggest that more study is in order. What about 'the so what?' It may be that seeing Swedenborgian strands in Kierkegaard ultimately would have more impact on Swedenborg studies than Kierkegaard studies, but that remains to be seen. The suggestion by Roland Green (1992: 11) that Kierkegaard read Dreams of A Spirit Seer is interesting, in this regard. It is interesting because, Kant's depiction of Swedenborg may have discouraged even Kierkegaard from ever wanting to mention an intellectual association or debt to him, if in fact he had one. Much more work is required to discover if he did. However, it is also interesting that Dreams does not appear in the Auction Protocol, but that five exemplars of Swedenborg's work do, as well as a German Summary of his theology, purchased before he wrote Either/Or. 
Strindberg with Swedenborg in the Foreground

In 1923 in a Provincetown, Rhode Island summer theatre Playbill, the celebrated playwright Eugene O'Neill wrote that August Strindberg was 'the most modern of the moderns' (Stockenström 1988a: 51). He continued by saying that Strindberg's 'behind-the-life plays' were a form of 'supernaturalism' that was 'peculiarly his own' (Stockenström 1988a: 51). Years later in his 1961 book, The Theater of the Absurd, Martin Esslin wrote at length about Strindberg's ground-breaking contribution to world drama:

Strindberg was the first to put on the stage a dream world in the spirit of modern psychological thinking. . .by delving into his own subconscious to discover the universal, collective significance of his own private obsessions. . . . In his dream plays To Damascus, A Dream Play, The Ghost Sonata, the shift from the objective reality of the world outside, from surface appearances to the subjective reality of inner states of consciousness-a shift that marks the watershed between the traditional and modern, the representational and the Expressionist projection of mental realities-is finally and triumphantly accomplished. (Stockenström 1988a: 51-2.)

As these quotes indicate Strindberg's impact on modern drama was enormous in the world at large, and by implication in Scandinavia, as well. However, according to Göran Stockenström, the revolutionary works of Strindberg, the ones that created his enduring legacy, were all written 'post-Inferno'. That is, they were written after his transformative encounter with Swedenborg during his mental and spiritual Inferno crisis in 1896/ 7 (Stockenström 1988a: 50-1).

The point at which Strindberg received a summary of Swedenborg's teaching from his mother-in-law, Marie Uhl was one of intense personal anxiety. He had strong feelings of persecution, heard and saw strange things-he wondered whether they were hallucinations, or visions. He wondered if he was going mad. He lived daily with inner fears and torments.

What arrested his attention was Swedenborg's description of hell. Predisposed to dismiss hell as an outdated prejudice, in Swedenborg's portrayals, he recognized the world around him. As he wrote, 'All the same I could not deny a matter of fact, they only thing I could do was to explain eternal damnation in this new way: we are already in hell.... It is thus that Swedenborg, perhaps without knowing it, depicts our earthly life when meaning to describe hell' (Strindberg 1979: 211). 
After receiving this book, Strindberg spent his days reading Swedenborg, and 'was overwhelmed by the realism of his descriptions. I found everything there,... his visions seemed things actually experienced, truly human documents. There was no question of blind faith' (Strindberg 1979: 214). What Strindberg regretted, however, was that the volume he had only contained extracts. It was not until later on, when the complete edition of Arcana Coelestia fell into my hands, that I was able to discover the answer to the principal riddles of our spiritual life' (Strindberg 1979: 214-15).

He had been introduced to several additional works of Swedenborg and the 'Swedenborgian' works of Balzac through his friends and acquaintances in the French Symbolist Movement (Stockenström 1988b: 143). ${ }^{8}$ As he wrote in a letter to the Theosophist Torsten Hedlund: 'Swedenborg is very important here. He is reckoned as the first Theosophist in modern times, before Allan Kardec. I often get to read that I am from the homeland of Swedenborg, etc. Thus I read Séraphita by Balzac. How great and wonderful it is' (Stockenström 1988b: 141).

In Seraphita Strindberg found reconciliation, in Earths in the Universe he found deliverance. As he wrote in the chapter on 'The Redeemer':

When Balzac, in his book Séraphita, introduced my sublime countryman Emanuel Swedenborg to men as the 'Buddha of the North', he showed me the evangelistic aspect of the prophet. Now it was the law that impressed me and set me free (Strindberg 1979: 256).

By a single word, just one, he brought light to my soul, dispelled my doubts, my vain speculations about my imaginary enemies the electrical experts and the practitioners of black magic, and this word was De/vastation (Strindberg 1979: 256).

Every physical and mental complaint that Strindberg had experienced he found documented in Swedenborg's descriptions of spirits from the planet Jupiter (Swedenborg 1996: 72-6). The ills originate in the process of chastisement by spirits aiming toward the good. What freed Strindberg was the belief that his afflictions were not a sign of his inherent evil, but that they came about as he was being disciplined-leading him to the

8 During this same period Strindberg had a close relationship with Munch, and Munch painted his portrait in 1896. 
good. He wrote, 'It all fits' (Stockenström 1988a: 66). This took away his fear and despair. He became convinced through Swedenborg's religious writings that suffering was an atonement. As he wrote:

By revealing to me the true nature of the terrors that had beset me during the past year, Swedenborg had set me free from the electrical experts, ... and the fear of insanity. He had shown me the only way to salvation: to seek out the demons in their lair, within myself, and to destroy them by repentance (Strindberg 1979: 261).

For Strindberg the outcome of his before and after experience in coming to terms with his suffering through his very personal interpretation of Swedenborg, was a new reality, a new beginning, a re-birth. He began to look at life in a new way. One key for him was Swedenborg's concept of 'Correspondences'.

As an author Strindberg viewed his mission in two ways: first, he believed he was chosen by God as he walked on his road to Damascus, and now his mission was to explain God's way to humanity; and second, in his role as a prophet, he was supposed to castigate a decadent society (Stockenström 1988a: 68). On a personal level, he felt compelled to make moral inventories of himself and to apologize to people he had unjustly made to suffer. In his stories he also became a moral example in Inferno (1897), Legends (1898), and Jacob Wrestles (1898) (Stockenström 1988a: 68). Overcoming his Inferno released tremendous energy in Strindberg and he entered a period of enormous productivity.

This understanding of Swedenborg's correspondences gave Strindberg the capability of creating the 'transformation scenes in the postInferno dramas. [They] became metaphysical unmaskings of the spiritual essence of the material world.' (Stockenström 1988b: 148.) In his dramas the idea of 'vastation' became an awaking that can lead to moral purification. In To Damascus the asylum scene clearly originated in Swedenborg's spirit world (Stockenström 1988b: 150). As Stockenström writes: 'It is striking how closely Strindberg followed Swedenborg when, with a sovereign dramatic instinct, he sought to realize the artistic intentions of the prototype, and orchestrated image, character, movement, and word into a unified metaphor for the stage' (Stockenström 1988b: 151).

In 1904 Strindberg wrote in his novel The Gothic Rooms, 'You don't read Swedenborg, but you receive him though grace, for he can only be understood by those who have similar experiences' (Stockenström 1988a: 69). Saved by his 'redeemer' Swedenborg in his Damascus ex- 
perience, Strindberg's productions after that retain and amplify his vast debt to his spiritual guide. Despite some disagreements, Swedenborg is his authority. In 1907 he dedicated his Blue Book to him: 'To Emanuel Swedenborg, Teacher and Leader, this is dedicated by a disciple' (Strindberg 1907). ${ }^{9}$

As Stockenström recognizes: 'Swedenborg's influence on Strindberg is not simply as a source of literary inspiration, but extends to the very depths of his being' (Stockenström 1988a: 69). It is, therefore, puzzling that in the nearly one hundred years since Strindberg's death no comprehensive study has been undertaken exploring this intimate relationship between 'The teacher and the disciple'.

Swedenborg clearly influenced all Strindberg's major innovations in letters and drama after 1897, and in that way his works were concrete examples of many of the revolutionary changes that occurred at the fin de siècle. As Strindberg wrote, about his symptoms, 'it all fits'; so one can write about Strindberg and the currents of the age, 'it all fits'! Swedenborg not only influenced Strindberg, but he also helped to shape the characteristics of the age that Strindberg fit so nicely into: the dissolutions of the very perception of reality; recognition that only the self or individual experience was real; external reality was only dreamlike images emanating for the soul; reality only exists in the individual, it is an idea of our consciousness, perhaps only a projection of our volition; reality if it exists is hidden behind a veil; true reality was not established by external observations, but only through intuition; contemplation, or ecstasy; focus on the unconscious mind led to different forms of occultism and transcendental mysticism. Esoteric currents held sway (Stockenström 1988b: 156).

In spite of the fact that Swedenborg's genuine influence on the age was not always apparent, Strindberg himself never lost sight of his debt. Toward the end, he wrote:

Is the end approaching? That I do not know but I have a presentiment. Life forces me out, it seems, or persecutes me, and I have long ago set my hopes 'to the other side,' to which I am connected like Swedenborg (Stockenström 1988a: 71). 


\section{Swedenborg's Contribution to Scandinavia: an Assessment}

The task of assessing Swedenborg's contribution to Scandinavia is not an easy one. On the surface, it would appear that he has made little impact, even where he is best known, in his homeland of Sweden. If asked today, few in Sweden or elsewhere in Scandinavia would know his name. This is true despite the fact that in three of the nations of Scandinavia, Sweden, Denmark, and Norway there are religious congregations devoted to living a life according to the teachings of Swedenborg. Except for the involvement of the esoterically sensitive Nordenskjöld family, few in Finland have been directly stirred by his message.

Just beneath the surface, however, at least part of his world-view has touched the taken-for-granted perspective in the West and Scandinavia of our modern sense of reality both external and internal, particularly our psychological self-understanding. He has entered into common consciousness through the works of Goethe, Balzac, Poe, and Dostoevsky. We resonate with those works, they speak to us, because he unmasked some universal truths about what it means to be human. Swedenborg's works were discovered by those authors, because he had a new view of our inner human nature that they understood-for he made it plain that it is there that we discover both heaven and hell. They understood that, and made Swedenborg's view concrete in their probing of the human heart. Munch absorbed Swedenborg at this level, and used the principals of Symbolism, many of which were drawn from Swedenborg to create his Frieze of Life.

Kierkegaard appears to have gone deeper than that, and as I have pointed out, the similarities between his Christian existentialism and Swedenborg's are quite remarkable. And Strindberg went even deeper, and on the most profound level acknowledged Swedenborg as his 'teacher and leader'.

So as I close, where does my effort leave us-'before of after'? I would say, I am still writing in the 'before'. I believe this article is a beginning but the real story of the place of Emanuel Swedenborg in the Scandinavian Saga has yet to be written, it is a drama with both exoteric and esoteric scenes, and I encourage others to join in its writing. 


\section{References}

\section{Selected Religious Works of Emanuel Swedenborg}

Earths in the Universe. In: Miscellaneous Theological Works; pp. 425-551. West Chester, PA: Swedenborg Foundation, 1996. (First published in 1758.)

Heaven and Hell. West Chester, PA: Swedenborg Foundation, 2002. (First published in 1758.)

Doctrine of the Lord. In: Four Doctrines; pp. 3-111. West Chester, PA: Swedenborg Foundation, 1997. (First published in 1763.)

Doctrine of Life. In: Four Doctrines; pp. 243-307. West Chester, PA: Swedenborg Foundation, 1997. (First published in 1763.)

Doctrine of the Sacred Scripture. In: Four Doctrines; pp. 313-52. West Chester, PA: Swedenborg Foundation, 1997. (First published in 1763.)

True Christianity. West Chester, PA: Swedenborg Foundation, 2006. (First published in 1771.)

\section{Bibliography}

\section{Anderson, Carl L.}

1973 Poe in Northlight: The Scandinavian Response to his Life and Work. Durham, NC: Duke University Press.

\section{Bering, Henrik}

2006 Henrik Bering on Edvard Munch: Behind the Scream, by Sue Prideaux. Policy Review. Hoover Institute, No. 136, April \& May http:/ / www.hoover.org / publications / policyreview / 3412176.html (accessed on 3 January 2008).

\section{Bischoff, Ulrich}

2000 Munch. Köln: Taschen.

\section{Burhan, Filiz Eda}

1979 Vision and Visionaries: Nineteen Century Psychological Theory: The Occult Sciences and The Formation of the Symbolist Aesthetic in France. Princeton University. UMI Dissertation Services.

\section{Cheetham, Mark A.}

1987 Mystical Memories: Gauguin's Neoplatonism and 'Abstraction' in Late Nineteenth-Century France. Art Journal 46 (Spring): 15-21.

\section{Eggum, Arne}

2007 Edvard Munch: A Norwegian Existentialist in Expressionist Art. Bienal Special Guests - Edvard Munch. http://www.1.uol.com.br/bienal/ 23bienal/especial/iemu.htm (accessed on 7 August 2007).

\section{Green, Roland M.}

1992 Kierkegaard and Kant: the Hidden Debt. Albany: SUNY.

Hong, Howard V. \& Edna Hong

2000 The Essential Kierkegaard. Princeton, NJ: Princeton University Press. 
Jörgensen, Johannes

1928 An Autobiography. Ingeborg Lund (trans.). London: Longmans, Green and Co.

\section{Milosz, Czeslaw}

1975 Dostoevsky and Swedenborg. Slavic Review 34 (2): 302-18.

Rohde, H. P. (ed.)

1967 The Auctioneer's Sales Records of the Library of Søren Kierkegaard. Copenhagen: The Royal Library.

\section{Stanford}

2006 Søren Kierkegaard. In: Stanford Encyclopedia of Philosophy. Revised May 11, 2006. http:/ / plato.stanford.edu/entries/kierkegaard/ (accessed on 4 January 2008).

\section{Stockenström, Göran}

1988a The Great Chaos and the Infinite Order: The Spiritual Journeys of Swedenborg and Strindberg. In: Erland Brock et al. (eds), Swedenborg and His Influence; pp. 47-78. Bryn Athyn, PA: Academy of the New Church.

1988b Strindberg and Swedenborg. In: Robin Larsen et al. (eds), Emanuel Swedenborg. A Continuing Vision; pp. 137-58. New York: Swedenborg Foundation.

\section{Strindberg, August}

1907 En Blå Bok. Stockholm: Björk \& Börjesson.

1979 Inferno/From an Occult Diary. Trans. Mary Sandbach. London: Penguin Books.

\section{Williams-Hogan, Jane}

1985 A New Church in a Disenchanted World: A Study of the Formation and Development of the General Conference of the New Church in Great Britain. Department of Sociology, University of Pennsylvania. Ann Arbor, MI: University Microfilms International. PhD Dissertation.

1998 Swedenborg's Place in Modern Western Esotericism. In: Antoine Faivre \& Wouter Hanegraaff (eds), Western Esotericism and the Science of Religion; pp. 201-52. Leuven: Peeters.

2004 Light and Dark in the Art of Edgar Allan Poe. In: Christopher Hartney \& Andrew McGarrity (eds), The Dark Side: Proceedings of the Seventh Australian and International Religion, Literature and the Arts Conference 2003; pp. 25-40. Sydney, Australia: RLA Press. 